\title{
The Effect of Job Satisfaction on the Organisational Commitment of Administrators
}

\author{
L J Thabane, PQ Radebe, M Dhurup \\ Vaal University of Technology, South Africa \\ leratok@vut.ac.za,patrick@vut.ac.za,manilalld@vut.ac.za
}

\begin{abstract}
Administrators are an important human resource in Higher Education because they perform various duties that are critical to the daily operations of universities. In light of this, organisational commitment and job satisfaction of administrators are essential for the efficiency and effectiveness of universities. Notwithstanding the critical relevance and necessity of organisational commitment and job satisfaction, there is evidence of paucity of research on these areas among administrative staff in the South African higher education sector. The objective of this study was to examine the relationship between organisational commitment and overall job satisfaction on the organisational commitment of administrators at a university in Gauteng. To achieve the aforementioned objective, a quantitative survey approach was used to examine the relationship between overall job satisfaction and organisational commitment. The selfadministered structured questionnaires were issued to 383 administrative staff members. Descriptive statistics was utilised to assess the levels of both organisational commitment and job satisfaction, results of which revealed that administrators were satisfied with and committed to the university. Spearman's rho correlation analysis showed that there was a strong correlation between affective commitment and job satisfaction; and moderate correlations between job satisfaction and moral imperative. Similar strong correlation was observed between indebted obligation and job satisfaction. Conversely, a weak correlation occurred between job satisfaction and continuance commitment. Regression coefficients indicated that job satisfaction contributed positively to the prediction of affective commitment, moral imperative, indebted obligation and continuance commitment. Based on these findings, the recommendations and future research opportunities were suggested.
\end{abstract}

Keywords: Job satisfaction, organisational commitment, higher education, university, and administrators

\section{Introduction}

The dynamic changes in the higher education (HE) sector have ignited the interest in organisational commitment and job satisfaction among researchers, as HE institutions battle to retain and satisfy employees (Kipkebut, 2010, p. 1). Some of the challenges that must be considered by the management of these institutions include the availability and subsequent management of human resources (Strydom, 2011, p. 15). Administrative staff members of HE institutions face the challenge of withstanding and surviving changes in the modern office. These changes and challenges can be seen in innovation and invention pertaining to equipment, furniture, form designs, nomenclature, environment, technology, attitudes, dress, responsibilities, training, skill, ability and knowledge (Onifade, 2010, p. 39). All these changes and challenges pose an enormous threat to the job satisfaction and organisational commitment of administrative staff. Notwithstanding the substantial amount of research in the areas of job satisfaction and organisational commitment in the HE sector (Martin \& Roodt, 2008, p. 23-31; Masemola, 2011, p. 104-111; Ismail, 2012, p. 44-51; Verret, 2012, p. 57-74), scant research has been conducted in these areas among administrative staff in this sector. It is, therefore, the prime objective of this study to fill the void by establishing linkage between organisational commitment and job satisfaction among administrative staff at a university in Gauteng. Empirical evidence supports the view that there has certainly been an exodus of administrative staff at South African HE institutions in the past decade or so (Netswera, Rankhumise \& Mavundla, 2005, p. 37). At the university under study, the Human Resource Department and Institutional Planning Unit attested that, between 2005 and 2013, the turnover rate of administrative staff has steadily been increasing with dire repercussions of replacement costs and work disruption.

\section{Literature Review}

Theoretical Framework of Job Satisfaction and Organisational Commitment: Various competing motivation theories are used to unravel the essence of job satisfaction. These theories attempt to explain the behaviour of people; how they feel and how they think (Booysen, 2008, p. 12). Many studies have used 
Maslow's hierarchy of needs theory; Alderfer's modified need hierarchy theory, McClelland's achievement motivation theory and the social exchange theory to explain job satisfaction and organisational commitment (Bernerth \& Walker, 2009, p. 217; Kipkebut, 2010, p. 61; Mullins, 2010, p. 260; Wikhamn \& Hall, 2012, p. 57). The current study utilises the less frequently used theories such as the Herzberg theory (job satisfaction) and side-bet theory (organisational commitment) to explicate the phenomena of job satisfaction and organisational commitment. Herzberg's two-factor theory forms the foundation for understanding the nature of job satisfaction in this study. Grobler, Warnich, Carell, Elbert and Hatfield (2009, p. 219) posit that hygiene factors reflect the context of the job. These factors are external to the employee and to the job. For this reason, they are perceived to be extrinsic in nature. These factors include salary, supervision, working conditions, job security and consistent management policies and rules. In contrast to hygiene factors, Grobler et al. $(2009$, p. 220$)$ postulate that motivators are intrinsic in nature and they reflect the content of the job. These factors represent higher-level needs and encapsulate achievement, responsibility, growth, the work itself and recognition (Hyun, 2009, p. 8). Ncube and Samuel (2014) consider them factors in the work environment that are pertinent to the gratification of the need for personal growth (Ncube \& Samuel, 2014, p. 270). Unlike hygiene factors, motivators are not manipulated externally but are innate to employees (Grobler et al., 2009, p. 220). Developed in 1960, Becker's side-bet theory posits that commitment, in general, is a disposition to engage in consistent lines of activity as a result of the accumulation of side-bets that would be lost if the activity was discontinued (Becker, 1960, p. 33). Meyer and Allen (1984, p. 373) describe side-bets as important things in which an employee has invested, that include money, effort and time that would be forfeited if the employee were to leave the organisation. It is the perceived threat of loss that commits a person to the organisation and is aggravated by a perceived lack of alternatives to replace or make up for the lost investments (Meyer \& Allen, 1984, p. 373).

Job Satisfaction: Job satisfaction has been researched extensively and researchers have varying ways of defining the concept (Al-Aameri, 2000, p. 532). Spector (1997, p. 2) defines job satisfaction as "how people feel about their jobs and different aspects of their jobs". Put differently, job satisfaction is considered as the extent to which people like (satisfaction) or dislike (dissatisfaction) their jobs. The literature on job satisfaction shows that it can be studied from two slightly different perspectives. First, job satisfaction may be perceived as a feeling an employee has and is directed to his/her own job. Alternatively, it may be observed as a multidimensional construct, where researchers focus on the different aspects that impact upon a job (Luthans, 2011, p. 141; Ravari, Mirzaei, Kazemi, Jamalizadeh, 2012, p. 97). Ample research has confined research to the use of multidimensional scale of job satisfaction (Allen, Lambert, Pasupuleti, Cluse-Tolar\& Ventura, 2004, p. 177; Radebe \& Dhurup, 2015, p. 716). In this study, a single-dimensional approach of job satisfaction was followed because the purpose of the study was to examine the relationship between job satisfaction as an overall concept and the various components of organisational commitment.

Notwithstanding the approach followed in this study, job satisfaction, as a multidimensional construct comprise three generally accepted dimensions. The first dimension is an emotional reaction to a job environment, which implies that job satisfaction cannot be seen, but can only be inferred. The second dimension relates to the determination how well outcomes meet or exceed expectations (Luthans, 2011, p. 141). The last dimension represents several related attitudes, which are the most important characteristics of a job about which people have affective responses. The job characteristics include the work itself, pay, promotion opportunities, supervision and co-workers' relationships (Luthans, 2011, p. 141). Oshagbemi (2013, p. 3) classifies sources of job satisfaction into two categories, namely intrinsic and extrinsic. The author explains that intrinsic sources originate from within the individual and have psychological value, whereas extrinsic sources originate from outside the individual, for example, the environment. Aziri (2011, p. 78) advances that job satisfaction is a worker's sense of achievement and success on the job. The author opines that job satisfaction implies doing a job one enjoys, doing it well and being rewarded for one's efforts. It also implies enthusiasm and happiness with one's work.

Organisational Commitment: The significance of organisational commitment lies in its potential to engender withdrawal behaviours and employee performance (Döckel, 2003, p. 34). Robbins (2001, p. 69) defines organisational commitment as "the extent to which an individual identifies with an organisation and is committed to that organisation, the attainment of its goals and wishes to maintain membership in the organisation". Meyer and Allen (1991, p. 67) define organisational commitment as "a psychological state that 
characterises the employee's relationship with the organisation and that has implications for the decision to continue membership in the organisation". Luthans (2011, p. 147) amplifies that employees with organisational commitment have a fervent aspiration to retain membership of an organisation, expend tremendous effort to attain organisational objectives and espouse the organisation's values and goals.

Meyer and Allen have enhanced insight into organisational commitment literature by professing a threecomponent model of organisational commitment, which encompasses the following components: normative commitment, affective commitment and continuance commitment (Jaros, 2007, p. 7). The normative commitment connotes an employee's feeling of moral obligation to stay with an organisation whereas affective commitment intimates an employee's emotional attachment to an organisation. Lastly, continuance commitment relates to the benefits that an employee would forfeit if he/she deserted an organisation (Meyer \& Allen, 1997). Current research indicates that the concept of normative commitment and its measurement using the normative commitment scale of Meyer and Allen has been problematic (Jaros, 2007, p. 12; Klein, Becker \& Meyer 2009:355). Several researchers postulate that normative commitment has a dual nature, namely it can be experienced as either a moral duty or a sense of indebtedness, each having different implications for work behaviour (Markovits, Ullrich, Van Dick \& Davis, 2008, p. 485; Meyer \& Parfyonova, 2010 , p. 283). Based on the above, Jaros (2007, p. 23) revised the original commitment scale of Allen and Meyer (1990) to reflect the indebted obligation and moral imperative dimensions of normative commitment. In view of this finding moral imperative and moral obligation were utilised in this study to assess the level of normative commitment.

Conceptual Model: The conceptual model in Figure 1 presupposes that a positive significant relationship exists between job satisfaction and organisational commitment (affective commitment, continuance commitment, indebted obligation and moral imperative). In view of the conceptual model, the following hypotheses were postulated:

H1: A positive association exists between moral imperative and job satisfaction.

H2: A positive link between continuance commitment and job satisfaction exists.

H3: Indebted obligations are positively related with job satisfaction.

H4: Affective commitment is positively associated with job satisfaction.

\section{Figure 1: Conceptual model}

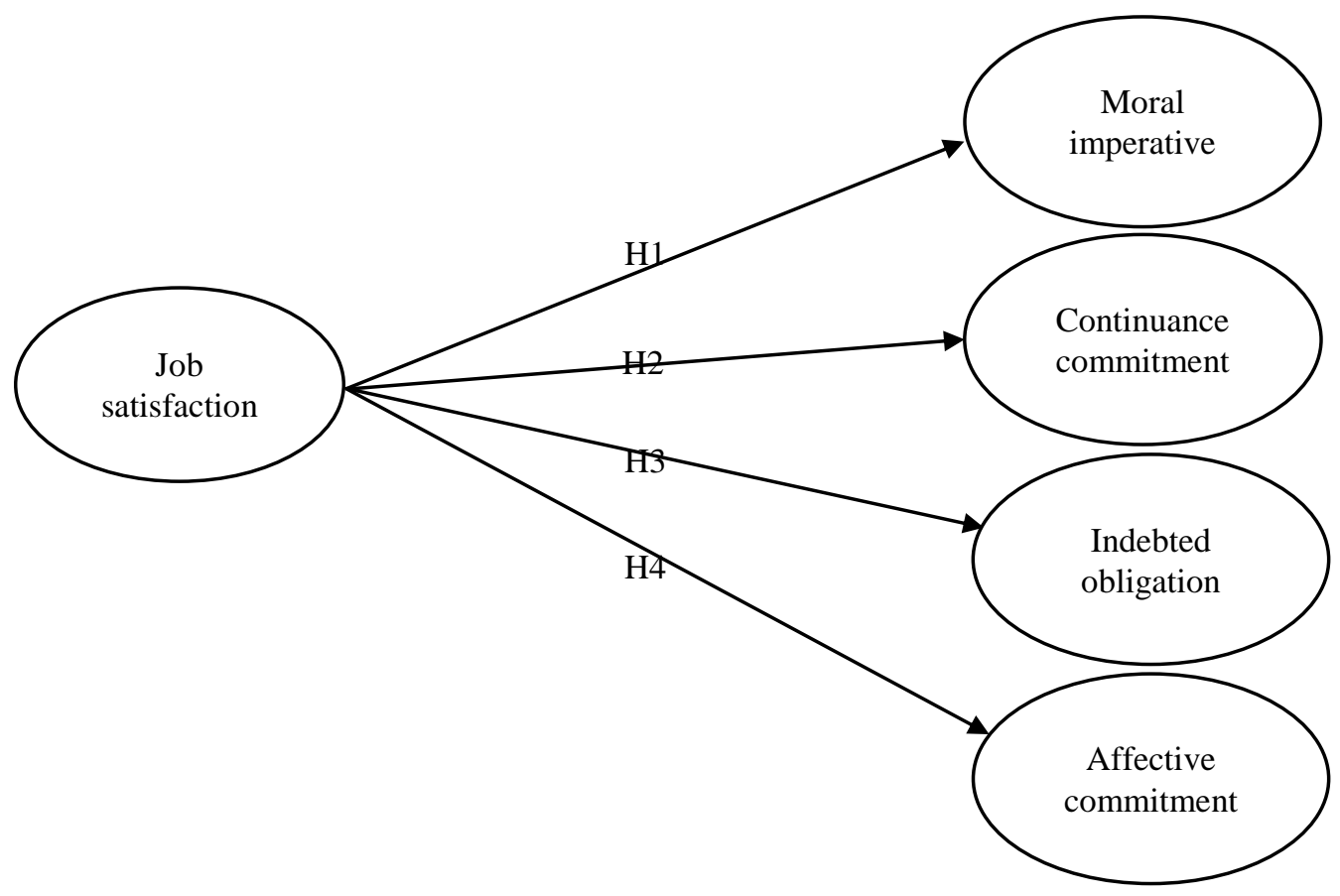




\section{Methodology}

Research Design: The research design utilised in this study was a quantitative survey approach, which made use of a structured questionnaire. The quantitative research approach was selected for this study to determine the relationship between the two variables, namely job satisfaction and organisational commitment.

Target Population and Sampling: The target population consisted of administrative staff of the university in Gauteng whose name cannot be disclosed for ethical reasons. The number of administrative staff at this university was 765 and the sample elements were drawn by using the convenience sampling method. A sample of $383(n=383)$ was selected using Leedy and Ormrod's $(2013$, p. 216) guideline of sample size selection. Leedy and Ormrod (2013, p. 216) advise that if the population is around 1500, 20 percent of the respondents should be sampled. Following Leedy and Ormrod's advice, a sample size of 383 respondents $(20 \% \times 765)$ was extracted out of a target population of 765 administrative staff members.

Method of Data Collection and Measuring Instrument: Data were collected through a structured questionnaire comprising three sections. Section A of the questionnaire focused on obtaining demographic information of the respondents. Section B was adapted from the overall job satisfaction scale designed by Brayfieldand Rothe in 1951. This scale was adapted because the emphasis in this study was to examine overall job satisfaction and not the facets of job satisfaction. Section C consisted of the organisational commitment questionnaire propounded by Meyer and Allen (1997) to assess the participants' attachment to their institution (Brown, 2003, p. 40). The adopted version was drawn from Jaros (2007, p. 23) and consisted of 20 items divided into sub-scales that measure the four factors of organisational commitment, namely affective commitment, continuance commitment, indebted obligation and moral imperative.

Reliability and Validity: The results of the reliability analysis of the measuring instrument indicated that the overall job satisfaction scale, Section B of the measuring instrument, consisted of five items and yielded a satisfactory reliability value of 0.884 . The value of Cronbach's alpha for the organisational commitment scale, Section C, was .863 indicating a high degree of internal consistency. The organisational commitment scale initially consisted of 20 items and during the factor analysis process; six items with a low or negative interitem correlation were deleted from the scale. The overall Cronbach alpha for the entire scale yielded an acceptable reliability value of .874 . Face validity was established through the pilot study. A total of 50 administrative staff members who were employed by the university were used for the pilot study. The respondents assessed the questionnaire in terms of its clarity, understandability, flow and construction. No changes were made to the questionnaire and the questionnaire was adopted for the main study. Content validity was achieved by evaluating if the statements in the questionnaire were relevant for the measurement of job satisfaction and organisational commitment. In this respect, five academics in the field of organisational behaviour confirmed that the items in the research instruments were relevant to the measurement of job satisfaction and organisational commitment. Construct validity was ascertained through exploratory factor analysis. Through factor analysis, four factors of organisational commitment were identified from the original 20 items of the organisational commitment scale.

\section{Results and Discussion}

Table 1: Eigenvalues, percentage of variance explained and cumulative percentage of organisational commitment

\begin{tabular}{lllll}
\hline Dimension description & $\begin{array}{l}\text { No } \\
\text { items }\end{array}$ & Eigenvalues & \% of variance & Cumulative \% \\
\hline Moral imperative & 4 & 5.275 & 37.675 & 37.675 \\
Continuance commitment & 4 & 2.111 & 15.076 & 52.751 \\
Indebted obligation & 3 & 1.114 & 7.960 & 60.711 \\
Affective commitment & 3 & 1.038 & 7.415 & 68.126 \\
\hline
\end{tabular}

Factor Analysis: Factor analysis was utilised to extract the pertinent factors that accounted for the intercorrelations among the 20 items of organisational commitment and to determine how strongly each item was 
related to the factors. The results of the factor analysis for organisational commitment with their attendant eigenvalues, the percentages of variance and the cumulative percentages are presented in Table 1 . Using the Kaiser-Guttman rule, also referred to as the Kaiser criterion or the eigenvalues $>1.0$ rule, only factors with eigenvalues equal to or greater than 1.0 were considered significant. Brown $(2015$, p. 23) stipulates that the logic of the Kaiser-Guttman rule is that when an eigenvalue is less than 1.0, the variance explained by a factor is less than the variance of a single indicator and is thus insignificant. The extraction method utilised during factor analysis was the principal component analysis (PCA) through varimax with Kaiser Normalization. Using these methods and guidelines resulted in the extraction of four factors. Previous studies (Kipkebut, 2010, p. 155; Celik, 2011, p. 144, Daneshfard \& Ekvaniyan, 2012, p. 176; Lumley, Coetzee, Tladinyane \& Ferreira, 2012, p. 110) had the proclivity to extract only three factors (affective commitment, normative commitment and continuance commitment). The extraction of four factors in this study is consistent with an empirical observation on discriminant validity in respect of normative commitment (Jaros, 2007, p. 12). This issue has been propounded upon in Section 2 of this paper.

Table 2: Factor loading matrix of organisational commitment

\begin{tabular}{|c|c|c|c|c|}
\hline Scale description & Factor 1 & Factor 2 & Factor 3 & Factor 4 \\
\hline $\begin{array}{l}\text { C16. "My organisation deserves my loyalty because of its } \\
\text { treatment towards me" }\end{array}$ & .832 & .237 & .091 & .129 \\
\hline $\begin{array}{l}\text { C18. "I am loyal to this organisation because my values are } \\
\text { largely its values" }\end{array}$ & .730 & .254 & .186 & .262 \\
\hline $\begin{array}{l}\text { C19. "This organisation has a mission that I believe in and am } \\
\text { committed to" }\end{array}$ & .745 & .101 & .187 & .340 \\
\hline $\begin{array}{l}\text { C20. "I feel it is 'morally correct' to dedicate myself to this } \\
\text { organization" }\end{array}$ & .765 & .219 & .174 & .195 \\
\hline $\begin{array}{l}\text { C10. "If I wasn't a member of this organisation, I would be } \\
\text { sad because my life would be disrupted" }\end{array}$ & .245 & .638 & .109 & .021 \\
\hline $\begin{array}{l}\text { C12. "I often feel anxious about what I have to lose with this } \\
\text { organization" }\end{array}$ & .100 & .725 & -.070 & .210 \\
\hline $\begin{array}{l}\text { C13. "Sometimes I worry about what might happen if } \\
\text { something was to happen to this organisation and I was no } \\
\text { longer a member" }\end{array}$ & .068 & .746 & .000 & .236 \\
\hline $\begin{array}{l}\text { C14. "I am dedicated to this organisation because I fear } \\
\text { what I have to lose in it" }\end{array}$ & .278 & .785 & -.044 & .009 \\
\hline C5. "I do not feel like 'part of the family' at my organization" & .146 & -.130 & .830 & .135 \\
\hline C6. "I do not feel 'emotionally attached' to this organization" & .086 & .056 & .787 & .245 \\
\hline $\begin{array}{l}\text { C8. "I do not feel a 'strong' sense of belonging to my } \\
\text { organization" }\end{array}$ & .218 & .056 & .819 & .024 \\
\hline C1. "I am very happy being a member of this organization" & .300 & .200 & .187 & .747 \\
\hline $\begin{array}{l}\text { C2. "I enjoy discussing about my organisation with people } \\
\text { outside it" }\end{array}$ & .146 & .144 & .104 & .837 \\
\hline $\begin{array}{l}\text { C7. "This organisation has a great deal of personal meaning } \\
\text { for me" }\end{array}$ & .313 & .122 & .163 & .705 \\
\hline
\end{tabular}

Extraction method: PCA with varimax with Kaiser Normalisation. Rotation converged in six iterations.

Factor Loading Matrix of Organisational Commitment: Table 2 displays the factor-loading matrix of the measuring instrument, which represents the summary of the final factor structure of organisational commitment. The principal component analysis (PCA) is a factor extraction method introduced by Karl Pearson in the early 1900s, used to discover and interpret the dependencies that exist among variables and to examine relationships that occur among variables (Timm, 2002, p. 445.). An item was considered if its factor loading was equal to or greater than 0.50. For this scale, items C3, C4, C9, C11, C15 and C17 were omitted from further analysis using the varimax with Kaiser normalisation method. These items were removed because their values for factor loading were low $(<0.50)$. Varimax minimises the number of variables that have high loadings on each factor with the goal of making small loadings even smaller, but maximises the number of high loadings on each variable. 
Factor 1, labelled moral imperative, comprised four items, which were responsible for 38 percent of the variance explained by the factor. Employees that have high levels of moral imperative strive to meet valued outcomes (Jaros, 2007, p. 12). Previous empirical evidence supports the conception that employees with moral imperative tend to have stronger intentions to stay in the organisation and enact greater discretionary performance (Barling \& Cooper, 2008, p. 44). Another study has demonstrated that a moral indebtednessis commonly associated with positive beliefs such as inspiration, meaningfulness, inherent goodness and optimism (Meyer \& Parfyonova, 2010, p. 287). The second factor was labelled continuance commitment and comprised four variables. The variables accounted for 15 percent of the variance explained. In respect of continuance commitment, empirical evidence suggests that, "employees with a strong continuance commitment remain with the organisation because they feel they need to" (Allen \& Meyer, 1990, p. 3). Other studies have similarly supported that continuancecommitment is likely to develop in response to conditions that increase the costs of cutting ties with the organisation (side-bets) (Powell \& Meyer, 2004, p. 159). In collaboration, Daneshfard and Ekvaniyan (2012, p. 169) observed that employees commit to the organisation because the costs of leaving are too high.

Factor 3 was labelled indebted obligation, comprising three items, which were responsible for 8 percent of the variance explained. The study of Jaros $(2007$, p. 12) illustrated that employees with this kind of commitment reflect the perceived need to meet others' expectations. In support, Meyer and Parfyonova (2010, p. 287) reflect that employees with indebted obligation tend to advance the interests of an organisation to avoid betrayal stigma for failing to do so. Failure to advance the interests of own organisation make employees develop negative feelings such as frustration, inconvenience and guilt. In contrast, the basic argument of Markovits et al. (2008, p. 6) maintains that different from the moral imperative dimension of commitment, when affective commitment is low and continuance commitment is high, normative commitment might be experienced as an indebted obligation, that is, 'something one has to do to meet obligations and/or save face'.

Finally, the fourth factor, labelled affective commitment, comprised three variables that accounted for 7 percent of the variance explained. The study of Jaros $(2007$, p. 12) provided evidence that employees who are affectively committed are emotionally attached to their organisations. This study is consistent with empirical evidence in the seminal work of Meyer and Allen (1991, p. 67), which suggested that employees with a strong affective commitment identify with the organisation and continue employment with the organisation because they want to do so. Powell and Meyer (2004, p. 159) concur that affective commitment is expected to have the strongest positive effect on desirable work behaviours such as attendance, performance and organisational citizenship behaviour. Greenberg and Baron (2003, p. 162) pursue the similar line of thought to the effect that employees who have affective commitment to their organisations persist to work for an organisation because they agree with its goals and values and desire to remain members of that organisation. Beck and Wilson cited in Mguqulwa (2008, p. 30) further amplify that employees who have high levels of affective commitment intend to stay with the organisation because they espouse the goals and values of the organisation. The four factors of organisational commitment accounted for 68 percent of the total variance explained.

Correlation Analysis: In this study, correlation was used to analyse the relationship, positive or negative, between the two variables, namely job satisfaction and organisational commitment. The method used to analyse and test the nature of the relationship between these variables was the Spearman's rho correlation coefficient test. The correlation results in Table 3 reveal a significantly strong relationship $\left(r=.504^{* *} ; \mathrm{p}<.000\right)$ between job satisfaction and affective commitment. This indicated that as the job satisfaction of the administrative staff members increased, they were inclined to develop an emotional attachment to the university. On the relationship between job satisfaction and moral imperative, there seemed to be a moderately significant and positive correlation among the variables $\left(r=.442^{* *} ; \mathrm{p}<.000\right)$. These results showed that as the job satisfaction of the administrators continued to improve, the more they felt morally obliged to continue employment with the university. The results of the correlation analysis also revealed a moderately significant relationship between job satisfaction and indebted obligation $\left(r=.309^{* *} ; \mathrm{p}<.000\right)$. These results indicated that an increased level of indebted obligation among administrative staff at the university was associated with job satisfaction. A weak relationship was observed between job satisfaction and continuance commitment $(\mathrm{r}=.133 ; \mathrm{p}<.000)$. This indicated that the continuance commitment of the administrative staff members to the university was not associated with the job satisfaction of the administrators. 
Table 3: Correlations-JS, moral imperative, continuance commitment, indebted obligation and affective commitment

\begin{tabular}{llllll}
\hline Spearman's rho & $\begin{array}{l}\text { Moral } \\
\text { Imperative }\end{array}$ & $\begin{array}{l}\text { Continuance } \\
\text { Commitment }\end{array}$ & $\begin{array}{l}\text { Indebted } \\
\text { Obligation }\end{array}$ & $\begin{array}{l}\text { Affective } \\
\text { Commitment }\end{array}$ & $\begin{array}{l}\text { Job } \\
\text { Satisfaction }\end{array}$ \\
\hline Moral imperative & 1.000 & & & & \\
Continuance commitment & $.455^{* *}$ & 1.000 & & & \\
Indebted obligation & $.374^{* *}$ & .061 & 1.000 & & \\
Affective commitment & $.589^{* *}$ & $.334^{* *}$ & $.378^{* *}$ & 1.000 & \\
Job satisfaction & $.442^{* *}$ & .133 & $.309^{* *}$ & $.504^{* *}$ & 1.000 \\
\hline
\end{tabular}

Other than the positive relationships between the four factors of organisational commitment and job satisfaction, correlations also were observed between the factors of organisational commitment. In this regard, a significantly strong relationship was found between moral imperative and affective commitment $(\mathrm{r}=$ $.589^{* *} ; \mathrm{p}<.000$ ). The results also reflected a significant moderate relationship between continuance commitment and moral imperative ( $\left.\mathrm{r}=.455^{* *} ; \mathrm{p}<.000\right)$. Meyer and Parfyonova (2010, p. 286) reported similar findings, which suggest a modest correlation between continuance commitment and normative commitment. On the association between indebted obligation and moral imperative, there seemed to be a statistically significant but moderate correlation $\left(\mathrm{r}=.374^{* *} ; \mathrm{p}<.000\right)$. This implied that the administrators remained committed to the university not only because of feelings of indebtedness, but also because they felt it was a morally right thing to do. Similar significant but moderate correlations were observed between affective commitment and continuance commitment $\left(\mathrm{r}=.334^{* *} ; \mathrm{p}<.000\right)$. A further implication is that the administrative staff members that were committed to the university because of their emotional attachment were also likely to remain in the employment of the university because the costs associated with leaving were too high. Lastly, the relationship between affective commitment and indebted obligation (normative commitment experienced as a sense of indebtedness) also revealed statistically significant but moderate correlations $\left(\mathrm{r}=.378^{* *} ; \mathrm{p}<.000\right)$.

Regression analysis: In this study regression, analysis was used to establish the predictive relationships between job satisfaction and the four factors of organisational commitment, namely moral imperative, continuance commitment, indebted obligation and affective commitment. The results of the regression analysis are presented in Table 4. Model 1 represents the regression analysis results of job satisfaction as a predictor of the moral imperative factor. In the examination of the coefficients of Model 1 displayed in Table 5 , the beta coefficient $(\beta=.488 ; \mathrm{p}<0.000)$ indicates that job satisfaction had played a significant role in the occurrence of moral imperative. As a result, the hypothesis that presupposed a significant positive relationship between job satisfaction and moral imperative (H1), was accepted. These results indicated that job satisfaction of the administrators contributed significantly to the prediction of moral imperative. This suggested that the administrators were content with their jobs and stayed committed to the university because they felt they ought to. Administrative staff members who were morally committed would strive to meet the objectives of the university. The results of the regression analysis in Model 1 also showed that 23 percent $(\mathrm{R} 2=.234)$ of the variation in the moral imperative dimension of organisational commitment could be attributed to job satisfaction. This suggested that if the job satisfaction of the administrators were to change, then the moral imperative factor of organisational commitment would change accordingly. This finding is supported by the study of Aydogdu and Asikgil (2011, p. 51) who found that job satisfaction contributed significantly in the prediction of organisational commitment, which is based on a strong belief that being a member of an organisation is the right and moral thing to do. The study attributed this predictive relationship to internal job satisfaction factors such as the use of skills, job variety, experience and performing things for others and external job satisfaction factors such as working condition, supervision, promotion and pay. 
Table 4: Regression analysis of job satisfaction as a predictor of the four factors of organisational commitment

\begin{tabular}{|c|c|c|c|c|c|}
\hline \multirow{3}{*}{$\begin{array}{l}\text { Model 1 } \\
\text { Independent variable: } \\
\text { Job satisfaction }\end{array}$} & \multicolumn{5}{|c|}{ Dependent variable: Factor 1 - Moral imperative } \\
\hline & \multicolumn{2}{|c|}{$\begin{array}{l}\text { Unstandardised } \\
\text { coefficients }\end{array}$} & \multicolumn{3}{|c|}{$\begin{array}{l}\text { Standardised } \\
\text { coefficients }\end{array}$} \\
\hline & $\mathrm{B}$ & Std. error & Beta & $\mathrm{t}$ & Sig \\
\hline & .551 & .069 & .488 & 7.984 & .000 \\
\hline \multicolumn{6}{|c|}{$\mathrm{R}=.488 \mathrm{a} ; \mathrm{R}^{2}=.238 ;$ Adjusted $\mathrm{R}^{2}=.234 ;$ Std. Error $=.81412 ; \mathrm{F}=63.739$} \\
\hline Model 2 & \multicolumn{5}{|c|}{ Dependent variable: Factor 2 - Continuance commitment } \\
\hline \multirow[t]{3}{*}{$\begin{array}{l}\text { Independent variable: } \\
\text { Job satisfaction }\end{array}$} & \multicolumn{2}{|c|}{$\begin{array}{l}\text { Unstandardised } \\
\text { coefficients }\end{array}$} & \multicolumn{3}{|c|}{$\begin{array}{l}\text { Standardised } \\
\text { coefficients }\end{array}$} \\
\hline & B & Std. error & Beta & $\mathrm{t}$ & Sig \\
\hline & .232 & .069 & .231 & 3.385 & .001 \\
\hline \multicolumn{6}{|c|}{$\mathrm{R}=.231 \mathrm{a} ; \mathrm{R}^{2}=.053 ;$ Adjusted $\mathrm{R}^{2}=.049 ;$ Std. Error $=.81013 ; \mathrm{F}=11.456$} \\
\hline Model 3 & \multicolumn{5}{|c|}{ Dependent variable: Factor 3 - Indebted obligation } \\
\hline \multirow[t]{3}{*}{$\begin{array}{l}\text { Independent variable: } \\
\text { Job satisfaction }\end{array}$} & \multicolumn{2}{|c|}{$\begin{array}{l}\text { Unstandardised } \\
\text { coefficients }\end{array}$} & \multicolumn{3}{|c|}{$\begin{array}{l}\text { Standardised } \\
\text { coefficients }\end{array}$} \\
\hline & B & Std. error & Beta & $\mathrm{t}$ & Sig \\
\hline & .347 & .076 & .306 & 4.589 & .000 \\
\hline \multicolumn{6}{|c|}{$\mathrm{R}=.306^{\mathrm{a}} ; \mathrm{R}^{2}=.094 ;$ Adjusted $\mathrm{R}^{2}=.089 ;$ Std. Error $=.89387 ; \mathrm{F}=21.063$} \\
\hline \multirow{4}{*}{$\begin{array}{l}\text { Model } 4 \\
\text { Independent variable: } \\
\text { Job satisfaction }\end{array}$} & \multicolumn{5}{|c|}{ Dependent variable: Factor 4 - Affective commitment } \\
\hline & \multicolumn{2}{|c|}{$\begin{array}{l}\text { Unstandardised } \\
\text { coefficients }\end{array}$} & \multicolumn{2}{|c|}{$\begin{array}{l}\text { Standardised } \\
\text { coefficients }\end{array}$} & \\
\hline & B & Std. error & Beta & $\mathrm{t}$ & Sig \\
\hline & .566 & .061 & .543 & 9.228 & .000 \\
\hline \multicolumn{6}{|c|}{$\mathrm{R}=.543^{\mathrm{a}} ; \mathrm{R}^{2}=.294 ;$ Adjusted $\mathrm{R}^{2}=.291 ;$ Std. Error $=.72460 ; \mathrm{F}=85.149$} \\
\hline
\end{tabular}

In Model 2, the regression coefficients reveal job satisfaction as a predictor of continuance commitment. The results in Table 4 pointed out that job satisfaction contributed positively to the prediction of continuance commitment $(\beta=.231 ; \mathrm{p}<0.001)$. Based on this finding, the hypothesis that suggested job satisfaction was positively related to continuance commitment was similarly supported. The implication was that the job satisfaction of the administrators at the university contributed to the incidence of continuance commitment. The more satisfied the administrators were with their jobs, the more committed they would be to their university due to the huge benefits they would forfeit if they were to sever ties with their organisation. The results of the second regression model analysis revealed that job satisfaction accounted for 5 percent $\left(R^{2}=\right.$ .049) of the variation in continuance commitment. This finding is consistent with the results of observations of Imam, Raza, Shah and Raza (2013, p. 274) who also found a significant predictive relationship between job satisfaction and continuance commitment. The results of the study established that an increase in the level of job satisfaction of employees would increase the continuance commitment of those employees. Employees, who were satisfied with their jobs, tended to display high levels of continuance commitment, thus they continued working for the organisation. Continued membership of an organisation could be ascribed to amicable employee relationships, non-transferable funds and investments like allowance, retirement fund or retirement remuneration, all of which have been found to be sources of job satisfaction (Imam et al., 2013, p. 272).

Model 3 reflects the regression values, which suggest that job satisfaction is a predictor of indebted obligation. The results, presented in Table 4, indicated that job satisfaction contributed positively to the prediction of indebted obligation with a beta coefficient of .306 at a significant level of $p<0.000$. The third hypothesis postulated that job satisfaction had a significant positive association with indebted obligation was accepted. This inferred that an increase in the level of job satisfaction of the administrators contributed significantly to the prediction of indebted obligation. Administrative staff members who were satisfied with their jobs would remain committed to the university because they felt they were obliged to. Model 3 suggests that the job satisfaction of the administrative staff members at the university accounted for 9 percent $\left(\mathrm{R}^{2}=\right.$ .089) of the variation in the prediction of indebted obligation. These results are in line with the findings of Lumley, Coetzee, Tladinyane and Ferreira (2011, p. 113) who also reported that there was a positive 
predictive relationship that existed between the normative commitment and job satisfaction. This indicates that job satisfaction induces moral indebtedness to retain membership of an organisation because of the need to comply with workplace social norms. These norms are epitomised by a sense of moral indebtedness to psychological contract between an employee and an employer. The obligations involve both objective economic exchanges (high performance-based pay, contingent pay, giving notice and working overtime) and subjective social exchanges (co-worker relationships, job security and employee loyalty). Meyer et al. cited in Bergman, Benzer, Kabins, Bhupatkar and Panina (2012, p. 155) concur that indebted obligations are exchange-based commitments, which last as long as situational signs are present.

Model 4 displays that job satisfaction has a predictive association with affective commitment. The regression results in Table 5 revealed that job satisfaction displayed significant predictive relationship with the affective commitment dimension of organisational commitment $(\beta=.543 ; \mathrm{p}<0.000)$. The fourth hypothesis, there is a positive relationship between job satisfaction and affective commitment, was accepted. A previous study conducted reported that affective commitment was positively associated with job satisfaction (Lumley et al., 2011, p. 112). According to the authors, the prevalence of a positive association between affective commitment and job satisfaction confirms that job satisfaction among employees tends to make them form strong emotional bonds with the organisation to an extent that they prefer to be highly involved in its activities. The coefficients of the regression analysis in Model 4 also demonstrated that job satisfaction accounted for 29 percent $\left(\mathrm{R}^{2}=.291\right)$ of the variation in the affective commitment of the administrative staff members at the university. These findings are consistent with those of Rhoades, Eseinberger and Armeli (2001, p. 825) who asserted that employees who had high levels of commitment were perceived to have considerable amounts of identification and belonging to the organisation and were more inclined to be involved in the activities of the organisation. They also expressed the desire to achieve the organisation's goals and showed intention to retain its membership. Finally, Meyer et al. (2002, p. 38) state that job satisfaction and affective commitment should both be considered in efforts to understand and manage employee behaviour because of the strength of the correlation between the two constructs.

\section{Conclusion}

The results reveal the existence of a positive association between job satisfaction and organisational commitment. Therefore, it was concluded that the more satisfied the administrative staff members were with their current jobs, the higher the level of commitment to the university. Finally, the findings were also very informative in exploring and explaining problems associated with behavioural aspects in organisations, particularly factors that contributed toward the organisational commitment and job satisfaction of administrators at the university.

Recommendations: The weak correlation and insignificant predictive association between continuance commitment and job satisfaction informed the recommendation that equitable salaries should be offered to the administrators. In essence, equitable salaries and benefits should be made competitive and marketrelated. Job satisfaction could also be improved through the provision of opportunities for career advancement and promotion opportunities. The university should invest in ongoing career advancement initiatives such as seminars, workshops, short courses, coaching and mentoring programs, aimed at improving the skills and competencies of administrative staff members. The university should also consider the development and consistent implementation of fair institutional policies and rules as a measure to ameliorate job satisfaction and organizational commitment. This could be achieved by allowing participation of administrative staff in the development of policies in areas that affect their work life. The conversion of administrative staff on contract positions to permanent positions is another option that should be pursued. Lastly, the moderate correlation between job satisfaction and indebted obligation necessitated the recommendation that the university should provide conducive working conditions in accordance with the Basic Conditions of Employment Act (75 of 1997) (BCEA). This could be done through the regulation of working hours and compensating the administrative staff members for overtime worked. Such favorable working conditions would enhance the job satisfaction of the administrators and increase their levels of commitment to the university. It is clear that a high degree of job satisfaction among administrators generates high levels of commitment to the university. Thus, the importance of job satisfaction cannot be overlooked if the university intends to improve the level of commitment of its administrative staff members. 
Future Research Opportunities: The main objective of this study was to investigate the effect of job satisfaction on the organisational commitment of administrators at a university in Gauteng. While the objectives of this study were, successfully realised, future research could explore the mediating role of demographic factors such as gender, marital status, age, education level, income category, length of time in the workplace and current job status, in the relationship between job satisfaction and organisational commitment. The moral imperative and indebted obligation dimensions of normative commitment are new in the organisational commitment literature. As organisational commitment continues to evolve, future studies could also consider exploring and researching these dimensions of normative commitment extensively.

\section{References}

Al-Aameri, A. S. (2000). Job satisfaction and organizational commitment for nurses. Saudi Medical Journal, 21(6), 531-535.

Allen, N. J. \& Meyer, J. P. (1990).The measurement and antecedents of affective, continuance, and normative commitment to the organization. Journal of Occupational Psychology, 63(1), 1-18.

Allen, R. I., Lambert, E. G., Pasupuleti, S., Cluse-Tolar, T. \& Ventura, L. A. (2004). The impact of job characteristics on social and human service workers. Social Work and Society, 2(2), 173-188.

Aydogdu, S. \& Asikgil, B. (2011). An empirical study of the relationship among job satisfaction, organizational commitment and turnover intention. International Review of Management \& Marketing, 1(3), 43-53.

Aziri, B. (2011). Job satisfaction: a literature review. Management Research and Practice, 3(4), 77-86.

Barling, J. \& Cooper, C. L. (2008). The SAGE handbook of organizational behaviour. London: Sage Publications.

Becker, H. S. (1960). Notes on the concept of commitment. American Journal of Sociology, 66(1), 32-42.

Bergman, M. E., Benzer, J. K., Kabins, A. H., Bhupatkar, A. \& Panina, D. (2012).An event-based perspective on the development of commitment. Human Resource Management Review, 23, 148-160.

Bernerth, J. B. \& Walker, H. J. (2009). Propensity to trust and the impact on social exchange. Journal of Leadership and Organizational Studies, 15(3), 217-226.

Booysen, C. (2008). A Study of the relationship between job satisfaction experienced by employees within a retail company and their organisational citizenship behaviour.MBC Dissertation. Cape Town: University of the Western Cape.

Breyfield, A. \& Rothe, H. (1951). An index of job satisfaction. Journal of Applied Psychology, 35, 307-311.

Brown, T. A. (2015). Confirmatory factor analysis for applied research ( $2^{\text {nd }}$ ed). New York: The Guilford Press.

Celik, C. (2011). Relationship of organisational commitment and job satisfaction: a field study of tax office employees. Turkey: Mersin University. (Unpublished).

Daneshfard, C. D. \& Ekvaniyan, K. E. (2012).Organizational commitment and job satisfaction in Islamic Azad University. Interdisciplinary Journal of Contemporary Research in Business, 3(9), 168-181.

Döckel, A. (2003). The effect of retention factors on organisational commitment: an investigation of high technology employees. MCom Dissertation. Pretoria: University of Pretoria.

Greenberg, J. \& Baron, R. A. (2003). Behavior in organizations. New Jersey: Pearson Education.

Grobler, P. A., Warnich, S., Carell, M. R., Elbert, N. F. \& Hatfield, R. D. (2009). Human resources management in South Africa ( $3^{\text {rd }}$ ed). London: Thompson Learning.

Hyun, S. (2009). Re-examination of Herzberg's two-factor theory of motivation in the Korean army foodservice operation. Masters Thesis. Ames: Iowa State University.

Imam, A., Raza, A. M., Shah, F. T. \& Raza, H. (2013). Impact of job satisfaction on facet of organizational commitment (affective, continuance and normative commitment): a study of banking sector employees of Pakistan. World Applied Sciences Journal, 28(2), 271-277.

Ismail, N. (2012). Organisational commitment and job satisfaction among staff of higher learning education institutions in Kelantan. MSc Dissertation. TOWN: Universiti Utara.

Jaros, S. (2007). Meyer and Allen model of organizational commitment: measurement issues. The ICFAI Journal of Organizational Behavior, 6(4), 7-25.

Kipkebut, J. D. (2010). Organisational commitment and job satisfaction in higher educational institutions: the Kenyan case. PhD Thesis. London: Middlesex University.

Klein, H. J., Becker, T. E., \& Meyer, J. P. (2009).Commitment in organizations: Accumulated wisdom and new directions. New York, NY: Taylor \& Francis.

Leedy, P. D. \& Ormrod, J. E. (2013). Practical research. Planning and design (10 ${ }^{\text {th }}$ ed). New Jersey: Pearson. 
Lumley, E. J., Coetzee, M., Tladinyane, R. \& Ferreira, N. (2011).Exploring the job satisfaction and organisational commitment of employees in the information technology environment. Southern African Business Review, 15(1), 100-118.

Luthans, F. (2011). Organizational Behaviour: An Evidence-Based Approach(12 ${ }^{\text {th }}$ ed). New York: McGraw-Hill.

Markovits, Y., Ullrich, J., Van Dick, R. \& Davis, A. J. (2008). Regulatory foci and organizational commitment. Journal of Vocational Behavior, 73, 485-489.

Martin, A. \& Roodt, G. (2008). Perceptions of organisational commitment, job satisfaction and turnover intentions in a post-merger South African tertiary institution. South African Journal of Industrial Psychology, 34(1), 23-31.

Masemola, S. E. (2011). Employee turnover intentions, organisational commitment and job satisfaction in a post-merger tertiary institution: the case of the University of Limpopo.MBA Mini-Dissertation. Polokwane: University of Limpopo.

Meyer, J. P. \& Allen, N. J. (1984). Testing the "side-bet theory" of organizational commitment: some methodological considerations. Journal of Applied Psychology, 69(3), 372-378.

Meyer, J. P. \& Allen, N. J. (1991). A three-component conceptualization of organizational commitment. Human Resource Management Review, 1, 61-89.

Meyer, J. P. \& Allen, N. J. (1997). Commitment in the workplace: Theory, research, and application. California: Sage Publications.

Meyer, J. P., Stanley, D. J., Herscovitch, L. \& Topolnytsky, L. (2002). Affective, continuance, and normative commitment to the organization: a meta-analysis of antecedents, correlates, and consequences. Journal of Vocational Behavior, 61(1), 20-52.

Meyer, J. P. \& Parfyonova, N. M. (2010). Normative commitment in the workplace: a theoretical analysis and re-conceptualization. Human Resource Management Review, 20(1), 283-294.

Mguqulwa, N. (2008). The relationship between organisational commitment and work performance in an agricultural company. MA Dissertation. Pretoria: University of South Africa.

Mullins, L. J. (2010). Management and organisational behaviour ( $9^{\text {th }}$ ed). Edinburgh: Financial Times Prentice Hall.

Netswera, F. G., Rankhumise, E. M. \& Mavundla, T. R. (2005). Employee Retention Factors for South African Higher Education Institutions: A Case Study. South African Journal of Human Resource Management, $3(2), 36-40$.

Ncube, C. M. \& Samuel, M. O. (2014).Revisiting employee motivation and job satisfaction within the context of an emerging economy: theoretical representation and developing the model. Mediterranean Journal of Social Sciences, 5(9), 267-282.

Onifade, A. (2010). The indispensable secretary. Journal of Social Sciences, 22(1), 47-51.

Powell, D. M. \& Meyer, J. P. (2004). Side-bet theory and the three-component model of organizational commitment. Journal of Vocational Behavior, 65(1), 157-177.

Radebe, P. Q. \& Dhurup, M. (2015). Sport and recreation officials' role innovation, job enjoyment and their relationship with job satisfaction and intention to stay in a developing country. African Journal for Physical, Health Education, Recreation and Dance, 21(3), 711-723.

Ravari, A., Mirzaei, T., Kazemi, M. \& Jamalizadeh, A. (2012).Job satisfaction as a multidimensional concept: A systematic review study. Journal of Occupational Health and Epidemiology, 1(2), 95-102.

Rhoades, L., Eisenberger, R. \& Armeli, S. (2001). Affective Commitment to the Organization: The Contribution of Perceived Organisational Support. Journal of Applied Psychology, 86(5), 825-836.

Robbins, S. P. (2001). Organizational behavior ( $9^{\text {th }}$ ed). New Jersey: Prentice-Hall.

South Africa. Basic Conditions of Employment Act. No. 75 of (1997). Cape Town: Butterworths.

Spector, P. E. (1997). Job satisfaction: application, assessment, cause, and consequences. California: Sage Publications.

Strydom, A. (2011). The Job Satisfaction of Academic Staff Members on Fixed-Term Employment Contracts at South African Higher Education Institutions. PhD. Thesis. Bloemfontein: University of the Free State.

Timm, N. H. (2002). Applied multivariate analysis. New York: Springer-Verlag.

Verret, L. B. (2012). Factors affecting university stem faculty job satisfaction. PhD Thesis. Louisiana: Louisiana State University.

Wikhamn, W. \& Hall, A. T. (2012). Social exchange in a Swedish work environment. International Journal of Business and Social Science, 3(23), 56-64. 